\title{
Physicochemical and Bacteriological Characteristics of Rainwater Harvested from Rooftops in Esan-West Local Government Area of Edo State, Nigeria
}

\author{
* EZEMONYE MN; ${ }^{1}$ ISUEKEN CO; ${ }^{3}$ EMERIBE CN
}

\author{
${ }_{1}$ Department of Geography and Regional Planning, University of Benin, Benin City, Edo State, Nigeria \\ ${ }_{2}$ National Centre for Energy and Environment, University of Benin, Benin, City, Edo State, Nigeria \\ Department of Geography and Regional Planning, University of Benin, Benin City \\ *Corresponding author's address E-mail: ezemonyemary@yahoo.com; +2348033418529
}

\begin{abstract}
Due to scarcity of potable water, rainwater harvesting from rooftop has been favoured as an alternative source of water supply by most rural communities in Nigeria. This study investigated the physicochemical and bacteriological characteristics of rainwater harvested from three different rooftop sheets in Esan West Local Government Area, Edo State. Parameters investigated include $\mathrm{pH}$, TSS, TDS, Turbidity, Acidity, $\mathrm{Ca} 2+, \mathrm{Fe}, \mathrm{Pb}, \mathrm{Cr}, \mathrm{TBC}, \mathrm{TCC}$ and E-coli. The results showed that mean values of harvested rainwater from all sampled rooftops are acidic especially at the onset of the raining season. TSS and TDS were highest in samples collected from Asbestos rooftop, followed by Aluminum rooftop while samples from galvanized Iron had the least irrespective of the rainfall event. Rainwater samples collected at the onset of rain had higher $\mathrm{Ca}^{2+}$ concentration than those collected at the peak of rain for all roof type with galvanized Iron rooftop catchment recording the highest concentration. Samples collected at the onset of the rain for all roof type had Fe concentrations above the WHO limit of $0.1 \mathrm{mg} / \mathrm{l}$ while those collected at the peak of rain had lesser values. Values of $\mathrm{pb}, \mathrm{Cr}$ were within WHO permissible limit. Analysis of microbial parameters revealed that samples collected from all rooftop and for both seasons exceeded WHO limit of $<100 \mathrm{cfu} / \mathrm{ml}$ for TBC. Rainwater samples collected from corrugated Asbestos rooftop had the highest bacterial load for both onset and peak of rain, followed by samples collected from Aluminum rooftop for the onset on rain. E-coli count was highest in water sample collected from corrugated Asbestos rooftop for onset and peak of rain. The Analysis of variance (ANOVA) shows that quality of rainwater harvested from galvanized Iron, Aluminum and Asbestos rooftop catchments does not significantly differ at 0.05 statistical thresholds among rooftop catchment although samples from asbestos rooftop catchment recorded highest contamination level. In view of the physicochemical and bacteriological results, harvested rainwater can be put to all forms of domestic use except for direct ingestion unless treated. (C) JASEM
\end{abstract}

http://dx.doi.org/10.4314/jasem.v20i3.29

Keyword: Rainwater harvesting, drinking-water, physicochemical, bacteriological parameters, Heavy metals, rainfall onset, rainfall peak

The increasing scarcity of water in terms of quality is fast becoming an unpleasant reality in many parts of the world and Nigeria is not an exception. According to Oyedotun (2012) Nigerians face daily problems in obtaining water for domestic purposes and other multifarious uses (Oyedotun, 2012). Similarly, Krebs (2010) showed that of the total population of Nigeria, less than 30 percent has access to adequate drinking water. Although Ifabiyi (2012) reported that the coverage of potable water in Nigeria was $20 \%$ in 1980 which later rose to $30 \%$ in 1991 and approximately $55 \%$ in 2007 , study by Oyedotun, (2012) has shown that the service level in some rural and urban areas in Nigeria is about 10 and 30 litres per capita per day (lpcd) respectively. In most cases in where they are water-stressed, women and children particularly girls spend most of their productive time trekking long distances sourcing for water (Manzungu 2004; Mathew, 2005), even when these water sources are of questionable quality. Vasudevan and Pathak (2005) reported that local people especially those living in the rural areas are not much aware of the health implication of using water from questionable source for household purposes as their primary concern is usually on getting enough water to meet their needs. The consumption and usage of contaminated and polluted water has been noted to be one of the most important causes of ill health and sicknesses, particularly in developing countries. Gbadegesin and Olorunfemi (2007) also pointed out that the scarcity of safe drinking water in the country is responsible for the spread of many water-related diseases. 
In response to increasing unavailability of potable drinking water there is now a renewed interest in rainwater harvesting $\mathrm{RWH}$ as alternative to surface water sources. Studies have argued that the most effective way to obtain fresh drinking water is to harvest rainwater (Zuckel et at., 2003; Badal, et al., 2016). RWH has received increased attention worldwide as an alternative source of potable and non-potable water supplies (Hatibu et al., 2006; Heyworth et al., 2006; Ghisi and Ferreira, 2007; Han, 2007; Amin and Han, 2009).Their argument according to Retamal and Turner (2010) include that the method promotes self-sufficiency and encourages water and energy conservation and results in permanent decrease in water demand (Grandet et al., 2010) and climate change adaptation measure (Jackson et al., 2001). Despite having some promising merits over other sources, rainwater use has frequently been rejected as a source of potable water supply on the grounds of its water quality concerns (Meera and Ahammed, 2006). As reported by several researchers harvested rainwater can contain significant amounts of pollutants such as heavy metals, nutrients and pathogens (Gromaire-
Mertz et al., 1999; Lye, 2002; Zhu et al., 2004; Evans, 2006; Yufen et al., 2008). Thus in determining the end use and the potential success of potable use of rainwater in the study area, the possible problems associated with its quality need to be assessed. This study therefore aims at assessing the physicochemical and bacteriological characteristics of rainwater harvested from rooftops in Esan-West Local Government area of Edo state, Nigeria.

\section{MATERIALS AND METHODS}

Study area: The study area is Esan West Local Government Area, Edo State. It is a geographically situated between Latitudes $6^{\circ} 43^{1} \& 6^{0} 45^{1}$ North of the equator and Longitudes $6^{\circ} 60^{1} \& 6^{\circ} 80^{1}$ East of the Greenwich Meridian (Fig. 1). The local relief of the area is 150 meters above sea level; however, some areas are as low as 50meters above sea level. Esan West belong has been identified as the source or head water of many streams and rivers some of which flow into the Benin Lowlands while other flow northwards into the river Niger.

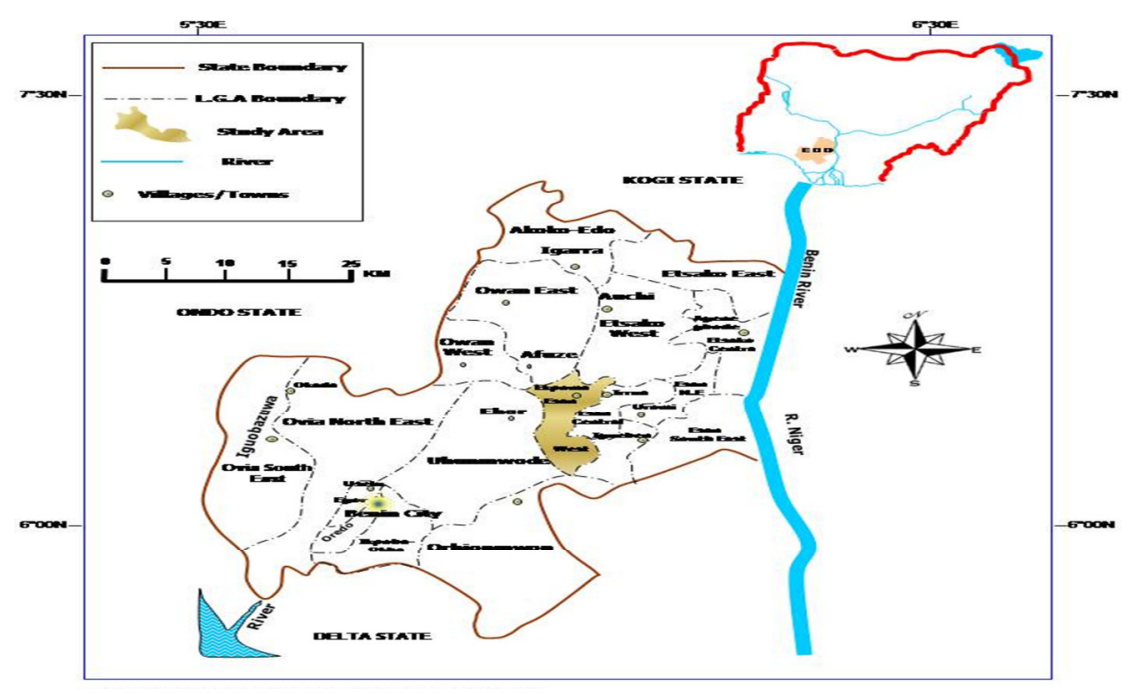

Fig.1: Edo state showing the study area

The study area has the tropical climate characterized by two seasons; these are wet and dry season. The wet seas

on occurs between April and October with a break in August while the dry season lasts from November to April with a cold harmattan spell between December and January. The temperature averages about $25^{\circ} \mathrm{C}$ $\left(77^{0} \mathrm{~F}\right)$ in the rainy season, and about $28^{\circ} \mathrm{C}\left(82^{0} \mathrm{~F}\right)$ in the dry season. The highest mean monthly temperature of $29.1^{\circ} \mathrm{C}$ is recorded in March and the lowest of $24.4^{\circ} \mathrm{C}$ in June (Aziegbe, 2006).
Data Collection: The Local Government Area was delineated into its already existing ten (10) political wards (Table 1) and rainwater samples collected from different rooftop from each ward. Three (3) roof types (i.e. Galvanized Iron, Aluminum and corrugated Asbestos roofing sheets) were considered for the study as they are common roof tops found in the study area. Three households of different roofing materials were randomly selected. Rainwater samples were collected during rainfall events for two 
sampling periods; onset and rainfall peak via rooftop runoff from the three selected roofing sheet materials (each for the ten (10) political wards) with the aid of pre-sterilized plastic containers connected to the selected rooftops.

Table 1: The 10 Political Wards in Esan West Local Council

\begin{tabular}{lll}
\hline S/NO & Town/Village & Wards \\
\hline $\mathbf{1}$ & Ogwa & 1 \\
$\mathbf{2}$ & Ujiogba/Ebute & 2 \\
$\mathbf{3}$ & Egoro/Idoa & 3 \\
$\mathbf{4}$ & Eguare / Emaudo & 4 \\
$\mathbf{5}$ & Ihimhudumu /Ugiemen, Ido-ebo/Uke & 5 \\
$\mathbf{6}$ & Iruekpen & 6 \\
$\mathbf{7}$ & Ukpenu /Emuhi & 7 \\
$\mathbf{8}$ & Urhohi & 8 \\
$\mathbf{9}$ & Uhiele & 9 \\
$\mathbf{1 0}$ & Ile & 10 \\
\hline
\end{tabular}

Samples were taken in February being onset of rainfall in the study area and July which being the peak of rainfall. A total of 64 samples were collected for analysis (i.e. 32 samples for each sampling period). Water samples were analyzed for physical, chemical, bacteriological and selected heavy metal content using standard method for the examination of water.

Data Analysis: Determination of Ph: The $\mathrm{pH}$ of the water samples was determined using the HANNA pH meter (model HI 8424). It was calibrated using buffer solutions 4.7 and 10.

Determination of Turbidity: Turbidity was read using a visible spectrophotometer VS721G. The cuvettes were washed and rinsed with distilled water. One of the cuvettes was filled to mark with the sample and the other was filled to mark with distilled water which was used to standardize the spectrophotometer. The sample was read at a wavelength of $420 \mathrm{~nm}$.

Determination of Total Dissolved Solids (TDS): The total dissolved solid (TDS) was analyzed using the HACH 44600-00 Conductivity/TDS meter. The probe was dipped into the container of the samples until a stable reading in $\mathrm{mg} / \mathrm{l}$ was obtained and recorded.
Determination of Total Suspended Solids (TSS): This is obtained by a simple subtraction method. The total solid was first determined and the total dissolved solid obtained was subtracted from it.

$\mathrm{TSS}=\mathrm{TS}-\mathrm{TDS}$

The total solid was obtained by gravimetric method: $10 \mathrm{ml}$ of the samples was measured into a preweighed evaporating dish which was oven dried at a temperature of $103^{\circ} \mathrm{C}$ to $105^{\circ} \mathrm{C}$ for two and half hour. The dish was cooled in a desiccator at room temperature and was weighed. The total solid was represented by the increase in the weight of the evaporating dish.

Total solids $(m g / l) \frac{(W 2-W 2) m g \times 1000}{m l \text { of sample used }}$

Where W1 = initial weight of evaporating dish

$\mathrm{W} 2$ = Final weight of the dish (evaporating dish + residue)

Determination of Heavy Metals ( $\mathrm{Fe}, \mathrm{Pb}, \mathrm{Cr})$ : To assess the levels of iron, lead and chromium, a portion of all the water samples $(50 \mathrm{ml})$ were initially subjected to fixing using concentrated nitric acid and concentrated hydrochloric acid in a ratio of 1:10 respectively. This was done in order to digest particulate matter inside the sample by heating carefully in a water bath to obtain thick yellow solution, and later was cooled and made up to $100 \mathrm{ml}$ with distilled water. After this fixing, the samples were directly analyzed using the Bulk Scientific AAS. JENWAY 6310 spectrophotometer and JENWAY PFP-7 flame photometer was used to determine magnesium.

Total Bacteria Count: $1 \mathrm{ml}$ of each sample was plated out using a serial dilution of 1:1000 $\left(10^{-3}\right)$. Molten nutrient agar was added to the petri dish and shaken for even distribution. Solidified nutrient agar plate was then incubated at a temperature of $37^{\circ} \mathrm{C}$ for 24hours. After incubation, emergence colonies were counted and colonies forming unit per ml calculated and recorded. Identification was done based on the cultural, morphological and biochemical tests of the isolates (Tables 2-4). Identification of Bacteria

Table 2: Cultural Characteristics

\begin{tabular}{ccccccc}
\hline ISOLATE & SIZE & SHAPE & COLOUR & MARGIN & ELEVATION & $\begin{array}{c}\text { SURFACE } \\
\text { COLONY }\end{array}$ \\
\hline A & $1 \mathrm{~mm}$ & Round & Pink & Smooth & Raised & Moist \\
B & $1 \mathrm{~mm}$ & Round & Yellow & Smooth & Raised & Dry \\
$\mathbf{C}$ & $1 \mathrm{~mm}$ & Round & Golden yellow & Smooth & Raised & Dry \\
$\mathbf{D}$ & $1 \mathrm{~mm}$ & Round & Green & Smooth & flat & Moist \\
$\mathbf{E}$ & $1 \mathrm{~mm}$ & Round & Cream & Rough & flat & Moist \\
\hline
\end{tabular}

Source: Author's Laboratory Analysis (2014). 
Table 3: Morphological Characteristics

\begin{tabular}{cccc}
\hline ISOLATE & $\begin{array}{c}\text { GRAM } \\
\text { REACTION }\end{array}$ & $\begin{array}{c}\text { CELLS } \\
\text { TYPE }\end{array}$ & $\begin{array}{c}\text { CELLS } \\
\text { ARRANGEMENT }\end{array}$ \\
\hline A & Negative & Rods & Singly \\
B & Positive & Cocci & Cluster \\
$\mathbf{C}$ & Positive & Cocci & Cluster \\
$\mathbf{D}$ & Negative & Rods & Singly \\
$\mathbf{E}$ & Negative & Rods & Singly \\
\hline
\end{tabular}

Source: Author's Laboratory Analysis (2014).

Table 4: Biochemical Characteristics

\begin{tabular}{cccccccc}
\hline ISOLATES & Coag. & Cat. & Ind. & Cit. & Oxid. & Lact. & Mot. \\
\hline $\mathbf{A}$ & Negative & Negative & Negative & Positive & Negative & Positive & Positive \\
B & Negative & Positive & Positive & Positive & Negative & Negative & Negative \\
C & Positive & Positive & Negative & Negative & Positive & Positive & Negative \\
D & Negative & Negative & Negative & Negative & Positive & Positive & Positive \\
E & Negative & Negative & Negative & Negative & Negative & Positive & Positive \\
\hline
\end{tabular}

Source: Author's Laboratory Analysis (2014).

Suspected Bacteria

$\mathrm{a}=$ Enterobacter;

$\mathrm{c}=$ Staph Epidy;

$\mathrm{e}=$ Klebsiella.

Key:

Coag. $=$ Coagulase test;

Ind. = Indole test;

Oxid. = Oxidase test;

Mot. $=$ Motility test. $\mathrm{b}=$ Micrococusspp;

$\mathrm{d}=$ Pseudomonas;

Cat. $=$ Catalase test

Cit. $=$ Citrate test;

Lact. $=$ Lactose test;

\section{Positive $=$ Present}

Negative $=$ Absent .

Total coliform count (Using MacConkey broth): The multiple tube technique (MTT) was employed and the 3 tube method was used. All tubes were incubated at a temperature of $37^{\circ} \mathrm{C}$ for $24 \mathrm{hrs}$ after which tubes showing colour changes (acid production) were regarded as positive tubes while those without a change in colour were discarded. The Magady Statistical Table was then used to get the value for the Most Probable Number (MPN) per $100 \mathrm{ml}$ and recorded.

E-coli count: The same method used in total coliform count was also employed here in determining the total E-Coli count except that all tubes were incubated at a temperature of $44^{0} \mathrm{C}$ for $24-48$ hours.

\section{RESULTS AND DISCUSSION}

The results of the laboratory analysis of physicochemical characteristics of rainwater samples collected at the onset of the raining season (February) and peak of rain (July) for different rooftop sheets are presented in Tables 5 and $6 . \mathrm{pH}$ levels for onset of rain (February) ranged from $5.0-6.5$ with a mean value of 5.9 for galvanized Iron rooftop; $5.0-6.4$ with a mean of 5.8 for Aluminum rooftop and 5.1 -
6.5 with a mean of 5.8 for corrugated Asbestos rooftop. Similarly, at the peak of the rain, $\mathrm{pH}$ levels ranges from $5.5-6.3$ with a mean 6.0 for Zinc rooftop; $5.2-6.1$ with a mean of 5.6 for Aluminum rooftop and $5.4-6.5$ with a mean of 6.0 for corrugated Asbestos rooftop respectively. The $\mathrm{pH}$ values of water samples obtained for all roof types indicate that they are below the World Health Organization (WHO) minimum permissible level for potable water $(6.15-9.50)$. Generally, mean values of harvested rainwater from all sampled rooftops are acidic especially at the onset of the raining season. Also the $\mathrm{pH}$ of samples collected showed variation from one roofing material to the other. Samples from Aluminum rooftop had the least $\mathrm{pH}$ values of 5.8 and 5.6 for onset and peak of the raining season respectively, indicating that it is more acidic than other roof types, while water samples from galvanized Iron and corrugated Asbestos rooftops had similar values of 5.8 and 6.0 for onset and peak of the raining season respectively. Acidic water can help prevent bacteria growth when used for kitchen cleaning, washing fresh fruits and vegetables. Thus, water samples collected from Aluminum rooftops had the best $\mathrm{pH}$ levels. 
Table 5: Physicochemical parameters quality of rainwater harvested from 3 different rooftop sheets (Onset of rainfall)

\begin{tabular}{|c|c|c|c|c|c|}
\hline Parameter & Rooftop type & Range & Mean & SD & $\mathbf{S E}$ \\
\hline \multirow[t]{3}{*}{$\mathrm{pH}$} & Galvanized Iron Rooftop & $5.0-6.5$ & 5.9 & 0.48 & 0.15 \\
\hline & Aluminum rooftop & $5-6.4$ & 5.8 & 0.46 & 0.15 \\
\hline & Asbestos rooftop & $5.1-6.5$ & 5.8 & 0.49 & 0.15 \\
\hline \multirow{3}{*}{$\begin{array}{l}\text { TSS } \\
\text { Mg/l }\end{array}$} & Galvanized Iron Rooftop & $0.01-0.08$ & 0.052 & 0.02 & 0.008 \\
\hline & Aluminum rooftop & $0.02-0.1$ & 0.06 & 0.027 & 0.009 \\
\hline & Asbestos rooftop & $0.04-0.1$ & 0.07 & 0.022 & 0.066 \\
\hline \multirow{3}{*}{$\begin{array}{l}\text { TDS } \\
\text { Mg/l }\end{array}$} & Galvanized Iron Rooftop & $10.8-26.5$ & 16.9 & 4.88 & 1.54 \\
\hline & Aluminum rooftop & $12.2-23.5$ & 17.19 & 3.6 & 1.13 \\
\hline & Asbestos rooftop & $19.5-37$ & 23.12 & 5.2 & 1.66 \\
\hline \multirow{3}{*}{$\begin{array}{l}\text { Turbidity } \\
\text { NTU }\end{array}$} & Galvanized Iron Rooftop & $0.09-0.95$ & 0.49 & 0.29 & 0.09 \\
\hline & Aluminum rooftop & $0.1-1.0$ & 0.5 & 0.3 & 0.096 \\
\hline & Asbestos rooftop & $0.4-1.2$ & 0.67 & 0.24 & 0.077 \\
\hline \multirow{3}{*}{$\begin{array}{l}\text { Acidity } \\
\text { Mg/l }\end{array}$} & Galvanized Iron Rooftop & $4-5.7$ & 4.83 & 0.61 & 0.19 \\
\hline & Aluminum rooftop & $4.1-5.8$ & 4.85 & 0.61 & 0.19 \\
\hline & Asbestos rooftop & $4.09-5.5$ & 4.79 & 0.47 & 0.15 \\
\hline \multirow{3}{*}{$\begin{array}{l}\mathrm{Ca} 2+ \\
\mathrm{Mg} / \mathrm{l}\end{array}$} & Galvanized Iron Rooftop & $69.5-122.3$ & 93.57 & 16.8 & 5.32 \\
\hline & Aluminum rooftop & $59.9-132.2$ & 91.21 & 22.7 & 7.17 \\
\hline & Asbestos rooftop & $55.5-145.5$ & 89.9 & 29.8 & 9.42 \\
\hline \multirow{3}{*}{$\begin{array}{l}\mathbf{F e} \\
\mathbf{M g} / \mathbf{l}\end{array}$} & Galvanized Iron Rooftop & $0.114-0.19$ & 0.14 & 0.026 & 0.008 \\
\hline & Aluminum rooftop & $0.095-0.156$ & 0.13 & 0.02 & 0.007 \\
\hline & Asbestos rooftop & $0.095-0.154$ & 0.14 & 0.012 & 0.0056 \\
\hline \multirow{3}{*}{$\begin{array}{l}\mathrm{Pb} \\
\mathrm{Mg} / \mathrm{l}\end{array}$} & Galvanized Iron Rooftop & $0.004-0.015$ & 0.007 & 0.004 & 0.001 \\
\hline & Aluminum rooftop & $0.003-0.014$ & 0.007 & 0.003 & 0.0009 \\
\hline & Asbestos rooftop & $0.003-0011$ & 0.008 & 0.0024 & 0.0008 \\
\hline \multirow{3}{*}{$\begin{array}{l}\mathrm{Cr} \\
\mathrm{Mg} / \mathrm{l}\end{array}$} & Galvanized Iron Rooftop & $0.011-0.026$ & 0.019 & 0.005 & 0.002 \\
\hline & Aluminum rooftop & $0.012-0.024$ & 0.018 & 0.005 & 0.002 \\
\hline & Asbestos rooftop & $0.014-0.025$ & 0.019 & 0.003 & 0.001 \\
\hline
\end{tabular}

The values of Total Suspended Solids (TSS) for the onset of the rain ranged from $0.01-0.08 \mathrm{mg} / \mathrm{l}$ with a mean of $0.052 \mathrm{mg} / 1$ for galvanized Iron rooftop; 0.02 $-0.1 \mathrm{mg} / \mathrm{l}$ with a mean of $0.06 \mathrm{mg} / \mathrm{l}$ for Aluminum rooftop and $0.04-0.1 \mathrm{mg} / 1$ with a mean of $0.07 \mathrm{mg} / \mathrm{l}$ for Asbestos rooftop.

Also, TSS values of rainfall peak ranges from < $0.005-0.009 \mathrm{mg} / \mathrm{l}$ with a mean of $0.0063 \mathrm{mg} / \mathrm{l}$ for galvanized Iron rooftop; $<0.005-0.03 \mathrm{mg} / \mathrm{l}$ with a mean of $0.009 \mathrm{mg} / \mathrm{l}$ for Aluminum rooftop and 0.005 $-0.05 \mathrm{mg} / \mathrm{l}$ with a mean of $0.015 \mathrm{mg} / \mathrm{l}$ for Asbestos rooftop. It is thus observable that irrespective of rainfall event (i.e. both onset and peak of rain) TSS was highest in samples collected from Asbestos rooftop; this is followed by samples from Aluminum rooftop while samples from galvanized Iron had the least. It is also observed that samples collected at the onset of the rain had higher amount of suspended solids than those collected at the peak of the rain for all roof type. This may be attributed to the accumulation of particulates from the air and droppings from birds, lizards etc. on the roofs during the long dry spell (October - January) before the onset of the rain. Although the threshold is not emphasized by the World Health Organization (WHO), TSS is known to reduce water transparency. Also, pathogens are often clumped or adherent to suspended solids in water (WHO, 2004). This implies that water samples collected from the three roof types does pose some health concerns, especially in households where harvested water is consumed directly without any form of purification.

The mean values for Total Dissolved Solids (TDS) of rainwater samples collected from galvanized Iron rooftop catchments were $16.9 \mathrm{mg} / \mathrm{l}$ and $7.9 \mathrm{mg} / \mathrm{l}$ for onset and peak of rain respectively, while the values ranged from $10.8-26.45 \mathrm{mg} / \mathrm{l}$ for onset of rain and $4.0-14.05 \mathrm{mg} / \mathrm{l}$ for peak of rain. 
Table 6: Physicochemical parameters quality of rainwater harvested from 3 different rooftop sheets (Peak of rainfall)

\begin{tabular}{|c|c|c|c|c|c|}
\hline Parameter & Rooftop type & Range & Mean & SD & SE \\
\hline \multirow[t]{3}{*}{$\mathrm{pH}$} & Galvanized Iron Rooftop & $5.5-6.3$ & 6.0 & 0.24 & 0.078 \\
\hline & Aluminum rooftop & $5.2-6.1$ & 5.6 & 0.29 & 0.09 \\
\hline & Asbestos rooftop & $5.4-6.5$ & 6.0 & 0.30 & 0.09 \\
\hline \multirow{3}{*}{$\begin{array}{l}\mathrm{TSS} \\
\mathrm{Mg} / \mathrm{l}\end{array}$} & Galvanized Iron Rooftop & 0.005-0.009 & 0.006 & 0.002 & 0.0005 \\
\hline & Aluminum rooftop & $0.005-0.03$ & 0.009 & 0.008 & 0.002 \\
\hline & Asbestos rooftop & $0.005-0.05$ & 0.015 & 0.012 & 0.005 \\
\hline \multirow{3}{*}{ Mg/l } & Galvanized Iron Rooftop & $4-14.1$ & 7.9 & 3.4 & 1.06 \\
\hline & Aluminum rooftop & $3.5-13$ & 6.7 & 2.9 & 0.92 \\
\hline & Asbestos rooftop & $5-37$ & 11.8 & 9.92 & 3.13 \\
\hline \multirow{3}{*}{$\begin{array}{l}\text { Turbidity } \\
\text { NTU }\end{array}$} & Galvanized Iron Rooftop & $0.03-0.1$ & 0.064 & 0.03 & 0.008 \\
\hline & Aluminum rooftop & $0.01-0.4$ & 0.13 & 0.15 & 0.05 \\
\hline & Asbestos rooftop & $0.03-0.3$ & 0.10 & 0.09 & 0.03 \\
\hline \multirow{3}{*}{$\begin{array}{l}\text { Acidity } \\
\mathrm{Mg} / \mathrm{l}\end{array}$} & Galvanized Iron Rooftop & $3.6-5.6$ & 4.46 & 0.63 & 0.19 \\
\hline & Aluminum rooftop & $3.02-5.58$ & 4.3 & 0.81 & 0.25 \\
\hline & Asbestos rooftop & $3.8-5.6$ & 4.7 & 0.67 & 0.21 \\
\hline \multirow{3}{*}{$\begin{array}{l}\mathrm{Ca} 2+ \\
\mathrm{Mg} / \mathrm{l}\end{array}$} & Galvanized Iron Rooftop & $40.1-115.7$ & 59.5 & 21.2 & 6.7 \\
\hline & Aluminum rooftop & $35.9-112.9$ & 58.3 & 20.7 & 6.5 \\
\hline & Asbestos rooftop & $38.6-117.5$ & 60.9 & 21.1 & 6.7 \\
\hline \multirow{3}{*}{$\begin{array}{l}\mathrm{Fe} \\
\mathrm{Mg} / \mathrm{l}\end{array}$} & Galvanized Iron Rooftop & $0.045-0.82$ & 0.14 & 0.24 & 0.07 \\
\hline & Aluminum rooftop & $0.029-0.095$ & 0.06 & 0.02 & 0.006 \\
\hline & Asbestos rooftop & $0.03-0.12$ & 0.06 & 0.03 & 0.008 \\
\hline \multirow{3}{*}{$\begin{array}{l}\mathrm{Pb} \\
\mathrm{Mg} / \mathrm{l}\end{array}$} & Galvanized Iron Rooftop & $0.003-0.008$ & 0.005 & 0.002 & 0.0006 \\
\hline & Aluminum rooftop & $0.002-0.013$ & 0.006 & 0.003 & 0.001 \\
\hline & Asbestos rooftop & $0.008-0.024$ & 0.007 & 0.004 & 0.001 \\
\hline \multirow{3}{*}{$\begin{array}{l}\mathrm{Cr} \\
\mathrm{Mg} / \mathrm{l}\end{array}$} & Galvanized Iron Rooftop & $0.008-0.024$ & 0.012 & 0.004 & 0.001 \\
\hline & Aluminum rooftop & $0.008-0.021$ & 0.02 & 0.005 & 0.002 \\
\hline & Asbestos rooftop & $0.012-0.026$ & 0.019 & 0.005 & 0.002 \\
\hline
\end{tabular}

Samples collected from Aluminum rooftop catchments had mean values of $17.19 \mathrm{mg} / \mathrm{l}$ and $6.66 \mathrm{mg} / \mathrm{l}$ of total dissolved solids for onset and peak of rain respectively and a range of $12.2-23.5 \mathrm{mg} / \mathrm{l}$ for onset of rain and $3.5-13.0 \mathrm{mg} / \mathrm{l}$ for peak of rain. Also, corrugated Asbestos had mean values of $23.12 \mathrm{mg} / \mathrm{l}$ and $11.75 \mathrm{mg} / \mathrm{l}$ for onset and peak of rain respectively with a range of $19.45-37.0 \mathrm{mg} / \mathrm{l}$ for onset of rain and $5.0-37.0 \mathrm{mg} / \mathrm{l}$ for peak of rain.

It was observed that rainwater samples collected from rooftop with corrugated Asbestos roofing sheets had higher concentration of dissolved solids, followed by samples collected from Aluminum rooftops while galvanized Iron rooftop had the least TDS concentration irrespective of the rainfall event. It is clear from the tables that the amount of dissolved solids decreases (for all roof type) from the onset of the rain to the peak. All samples collected (both for onset and peak of rain) had total dissolved solid concentrations below WHO limit $(500 \mathrm{mg} / \mathrm{l})$. Although no health based guideline value for Total Dissolve Solid (TDS) has been proposed, the presence of high levels of TDS (above $500 \mathrm{mg} / \mathrm{l}$ ) may become objectionable to consumers owing to excessive scaling in heaters, boilers and other household appliances (WHO, 2004 and 2011).

Turbidity values for rainwater samples collected from rooftop with galvanized Iron roofing sheets ranges from $0.09-0.95 \mathrm{NTU}$ with a mean of $0.49 \mathrm{NTU}$ for onset of rain and $0.03-0.10 \mathrm{NTU}$ with a mean of $0.064 \mathrm{NTU}$ for peak of rain. Aluminum rooftop had turbidity values ranging from $0.1-1.0 \mathrm{NTU}$ with a mean of $0.5 \mathrm{NTU}$ for onset of rain and $0.01-0.4 \mathrm{NTU}$ with a mean of $0.13 \mathrm{NTU}$ for peak of rain while corrugated Asbestos had values ranging from $0.4-$ $1.2 \mathrm{NTU}$ with a mean of $0.67 \mathrm{NTU}$ and $0.03-0.3 \mathrm{NTU}$ with a mean of $0.1 \mathrm{NTU}$ for onset and peak of rain respectively. The turbidity values decreases from the onset of rain to the peak for all roof type. Rainwater samples collected from Asbestos rooftop yielded highest turbidity levels. This was followed by samples collected from galvanized Iron rooftop whiles samples collected from Aluminum yielded the least turbidity levels for both onset and peak of rain. The turbidity values of all rainwater samples collected including the onset and peak of rain season 
are within the WHO limits of $0.2-1.0 \mathrm{NTU}$. Mean turbidity values at the onset of the rain for all roof type were above the WHO lower limit of $0.2 \mathrm{NTU}$, while samples collected at the peak of the rain were below the WHO lower limit of $0.2 \mathrm{NTU}$ for all roof type.

Rainwater samples collected from galvanized Iron rooftop catchments had mean acidity level of $4.83 \mathrm{mg} / \mathrm{l}$ with a range of $4.00-5.70 \mathrm{mg} / \mathrm{l}$ for onset of rain and a mean of $4.46 \mathrm{mg} / \mathrm{l}$ with a range of 3.60 $5.60 \mathrm{mg} / \mathrm{l}$ for peak of rain. Samples from Aluminum rooftop catchments had a range of $4.10-5.80 \mathrm{mg} / \mathrm{l}$ with a mean of $4.85 \mathrm{mg} / \mathrm{l}$ for onset of rain and $3.02-$ $5.80 \mathrm{mg} / \mathrm{l}$ with a mean $4.30 \mathrm{mg} / \mathrm{l}$ for peak of rain, while samples from Asbestos rooftop catchments had a range of $4.10-5.50 \mathrm{mg} / \mathrm{l}$ with a mean of $4.79 \mathrm{mg} / \mathrm{l}$ for onset of rain and $4.00-5.60 \mathrm{mg} / \mathrm{l}$ with a mean of $4.71 \mathrm{mg} / 1$ for peak of rain.

The concentration of $\mathrm{Ca}^{2+}$ in samples collected from galvanized Iron rooftop catchments ranged from 69.5 $-122.3 \mathrm{mg} / \mathrm{l}$ with a mean of $93.57 \mathrm{mg} / \mathrm{l}$ for onset of rain and $40.1-115.7 \mathrm{mg} / \mathrm{l}$ with a mean of $59.5 \mathrm{mg} / \mathrm{l}$ for peak of rain. Samples collected from Aluminum rooftop catchments had values ranging from 59.8 $132.2 \mathrm{mg} / \mathrm{l}$ with a mean of $91.2 \mathrm{mg} / \mathrm{l}$ for onset of rain and $35.9-112.9 \mathrm{mg} / \mathrm{l}$ with a mean of $58.3 \mathrm{mg} / \mathrm{l}$ for peak of rain. Samples from Asbestos rooftop catchments had a range value of $55.5-145.5 \mathrm{mg} / \mathrm{l}$ with a mean of $89.9 \mathrm{mg} / \mathrm{l}$ and $38.6-117.5 \mathrm{mg} / \mathrm{l}$ with a mean of $60.9 \mathrm{mg} / \mathrm{l}$ for onset and peak of rain respectively. Generally, samples collected from galvanized Iron rooftop catchments had the highest $\mathrm{Ca}^{2+}$ content and followed by samples collected from Aluminum rooftop catchments while samples from Asbestos rooftop had the least concentration. The rainwater samples collected at the onset of rain had higher $\mathrm{Ca}^{2+}$ concentration than those collected at the peak of rain for all roof type. Calcium ion $\left(\mathrm{Ca}^{2+}\right)$ concentration at the onset of rain were higher than WHO limit of $75 \mathrm{mg} / 1$ for $\mathrm{Ca}^{2+}$ in potable water while the concentration were lower than the limit at the peak of rain for all roof type.

The rainwater samples collected at the onset of the rain had Iron $(\mathrm{Fe})$ values ranging from 0.114 $0.199 \mathrm{mg} / \mathrm{l}$ with a mean of $0.14 \mathrm{mg} / \mathrm{l}$ for galvanized Iron rooftop catchments; $0.095-0.155 \mathrm{mg} / \mathrm{l}$ with a mean of $0.13 \mathrm{mg} / \mathrm{l}$ for Aluminum rooftop catchments and $0.099-0.154 \mathrm{mg} / \mathrm{l}$ with a mean of $0.14 \mathrm{mg} / \mathrm{l}$ for corrugated Asbestos rooftop catchments. Samples collected at the peak of rain had Iron $(\mathrm{Fe})$ concentration ranging from $0.045-0.082 \mathrm{mg} / \mathrm{l}$ with a mean of $0.14 \mathrm{mg} / \mathrm{l}$ for galvanized Iron rooftop catchments; $0.029-0.095 \mathrm{mg} / \mathrm{l}$ with a mean of $0.06 \mathrm{mg} / \mathrm{l}$ for Aluminum rooftop catchments and $0.032-0.121 \mathrm{mg} / \mathrm{l}$ with a mean of $0.06 \mathrm{mg} / \mathrm{l}$ for corrugated Asbestos rooftop catchments. Samples collected at the onset of the rain for all roof type had Fe concentrations above the WHO (2011) limit of $0.1 \mathrm{mg} / \mathrm{l}$ while those collected at the peak of rain had lesser values. Samples collected from galvanized Iron rooftop had the highest mean $\mathrm{Fe}$ value $(0.15 \mathrm{mg} / \mathrm{l})$ at the onset of the rain, while those collected from both Aluminum and Asbestos rooftops had similar mean values $(0.13 \mathrm{mg} / \mathrm{l})$.

The rainwater samples collected at the onset of rain from the three (3) roof types had Lead concentration levels ranging from $0.004-0.015 \mathrm{mg} / \mathrm{l}$ with a mean of $0.007 \mathrm{mg} / \mathrm{l}$ for galvanized Iron rooftop catchments; $0.003-0.014 \mathrm{mg} / \mathrm{l}$ with a mean of $0.007 \mathrm{mg} / \mathrm{l}$ for Aluminum rooftop and $0.003-0.011 \mathrm{mg} / \mathrm{l}$ with a mean of $0.008 \mathrm{mg} / \mathrm{l}$ for corrugated Asbestos rooftop. Samples collected at the peak of the rain had Lead concentration ranging from $0.003-0.008 \mathrm{mg} / \mathrm{l}$ with a mean value of $0.005 \mathrm{mg} / \mathrm{l}$ for galvanized Iron rooftop; $0.002-0.013 \mathrm{mg} / \mathrm{l}$ with a mean of $0.006 \mathrm{mg} / \mathrm{l}$ for Aluminum rooftop and $0.002-0.019 \mathrm{mg} / \mathrm{l}$ with a mean of $0.007 \mathrm{mg} / \mathrm{l}$ for corrugated Asbestos rooftop. All rainwater samples collected (irrespective of roof type and sampling season) had lead levels within the WHO limit of $0.01 \mathrm{mg} / \mathrm{l}$ for potable water.

The mean values of chromium concentration of rainwater samples collected from three different roof types. Chromium levels of rainwater samples collected at the onset of the rain ranged from $0.011-$ $0.026 \mathrm{mg} / \mathrm{l}$ with a mean of $0.019 \mathrm{mg} / \mathrm{l}$ for galvanized Iron rooftop; $0.012-0.024 \mathrm{mg} / \mathrm{l}$ with a mean of $0.018 \mathrm{mg} / 1$ for Aluminum rooftop and 0.014 $0.025 \mathrm{mg} / \mathrm{l}$ with a mean of $0.020 \mathrm{mg} / \mathrm{l}$ for Asbestos rooftop. At the peak of rain, Chromium levels ranged from $0.008-0.024 \mathrm{mg} / \mathrm{l}$ with a mean of $0.018 \mathrm{mg} / \mathrm{l}$ for galvanized Iron rooftop; $0.008-0.021 \mathrm{mg} / \mathrm{l}$ with a mean of $0.015 \mathrm{mg} / \mathrm{l}$ for Aluminum rooftop and 0.012 $-0.026 \mathrm{mg} / \mathrm{l}$ with a mean of $0.019 \mathrm{mg} / \mathrm{l}$ for Asbestos rooftop. All rainwater samples collected had Chromium levels within the WHO limit of $0.05 \mathrm{mg} / \mathrm{l}$. 
Table 7: Bacteriological parameters quality of rainwater harvested from 3 different rooftop sheets (Onset of rainfall)

\begin{tabular}{llllll}
\hline Parameter & Rooftop type & Range & Mean & SD & SE \\
\hline TBC & Galvanized Iron Rooftop & $100-200$ & 130 & 48.3 & 15.3 \\
Cfu/ml & Aluminum rooftop & $100-300$ & 150 & 70.7 & 22.4 \\
& Asbestos rooftop & $100-500$ & 260 & 117.4 & 37.11 \\
TCC & Galvanized Iron Rooftop & $0.4-1.0$ & 0.74 & 0.27 & 0.087 \\
MPN/100ml & Aluminum rooftop & $0.2-2.0$ & 0.96 & 0.61 & 0.19 \\
& Asbestos rooftop & $0.5-30$ & 1.49 & 0.82 & 0.26 \\
E-coli & Galvanized Iron Rooftop & $0.03-0.4$ & 0.08 & 0.11 & 0.04 \\
MPN/100ml & Aluminum rooftop & $0.03-0.1$ & 0.05 & 0.02 & 0.08 \\
& Asbestos rooftop & $0.03-0.7$ & 0.24 & 0.24 & 0.08 \\
\hline
\end{tabular}

Tables 7 and 8 shows the mean bacteria count in rainwater samples collected from rooftops made of three different materials. The Total Bacteria Count (TBC) in rainwater samples collected at the onset of the rain range between $100-200 \mathrm{cfu} / \mathrm{ml}$ with a mean of $130 \mathrm{cfu} / \mathrm{ml}$ for galvanized Iron rooftop catchments; $100-300 \mathrm{cfu} / \mathrm{ml}$ with a mean of $150 \mathrm{cfu} / \mathrm{ml}$ for Aluminum rooftop catchments and $100-500 \mathrm{cfu} / \mathrm{ml}$ with a mean of $260 \mathrm{cfu} / \mathrm{ml}$ for corrugated Asbestos rooftop catchments. Samples collected at the peak of the rain had TBC ranging from $100-200 \mathrm{cfu} / \mathrm{ml}$ with a mean of $110 \mathrm{cfu} / \mathrm{ml}$; samples from Aluminum rooftops had a count of $100 \mathrm{cfu} / \mathrm{ml}$ for all sampled
Aluminum rooftop while samples from corrugated Asbestos rooftop catchments had a range of 100$200 \mathrm{cfu} / \mathrm{ml}$ with a mean $1700 \mathrm{cfu} / \mathrm{ml}$. Samples collected from all rooftop (for both seasons) exceeded WHO limit of $<100 \mathrm{cfu} / \mathrm{ml}$ for TBC. Also, samples collected at the onset of rain for all roof type had higher bacterial load than those collected at the peak of rain. Generally, rainwater samples collected from corrugated Asbestos rooftop had the highest bacterial load for both onset and peak of rain, followed by samples collected from Aluminum rooftop for the onset on rain

Table 8: Bacteriological parameters quality of rainwater harvested from 3 different rooftop sheets (Peak of rainfall)

\begin{tabular}{llllll}
\hline Parameter & Rooftop type & Range & Mean & SD & SE \\
\hline TBC & Galvanized Iron Rooftop & $100-200$ & 110 & 31.6 & 10 \\
Cfu/ml & Aluminum rooftop & $100-200$ & 110 & 31.6 & 10 \\
& Asbestos rooftop & $100-200$ & 170 & 48.3 & 15.3 \\
TCC & Galvanized Iron Rooftop & $0.1-0.5$ & 0.3 & 0.16 & 0.054 \\
MPN/100ml & Aluminum rooftop & $0.1-0.5$ & 0.33 & 0.17 & 0.05 \\
& Asbestos rooftop & $0.1-0.5$ & 0.45 & 0.13 & 0.04 \\
E-coli & Galvanized Iron Rooftop & $0-0.05$ & 0.024 & 0.02 & 0.006 \\
MPN/100ml & Aluminum rooftop & $0-0.08$ & 0.033 & 0.02 & 0.006 \\
& Asbestos rooftop & $0.03-0.05$ & 0.035 & 0.009 & 0.003 \\
\hline
\end{tabular}

The total coliform count of samples collected at the onset of the rain ranged from $0.4-1.0$ Most Probable Number per $100 \mathrm{ml}$ (MPN/100ml) with a mean of $0.74 \mathrm{MPN} / 100 \mathrm{ml}$ for galvanized Iron rooftop; $0.2-$ $2.0 \mathrm{MPN} / 100 \mathrm{ml}$ with a mean of $0.96 \mathrm{MPN} / 100 \mathrm{ml}$ for Aluminum rooftop and $0.5-3.0 \mathrm{MPN} / 100 \mathrm{ml}$ with a mean of $1.49 \mathrm{MPN} / 100 \mathrm{ml}$ for corrugated Asbestos rooftop. Samples collected at the peak of rain had Total Coliform Count (TCC) which ranged from 0.1 - $0.5 \mathrm{MPN} / 100 \mathrm{ml}$ with a mean of $0.3,0.33$ and $0.45 \mathrm{MPN} / 100 \mathrm{ml}$ for galvanized Iron, Aluminum and corrugated Asbestos rooftop respectively. All samples collected had detectable Coliform count per
$100 \mathrm{ml}$ as against WHO standard which states that total coliform bacteria must not be detectable in any $100 \mathrm{ml}$ sample of water $(0 \mathrm{MPN} / 100 \mathrm{ml})$. Samples with the highest percentage of Coliform count were those from corrugated Asbestos rooftop, followed by those from Aluminum rooftop while galvanized Iron had the least probable number of coliform count for both onset and peak of rain. Generally, samples collected at the onset of rain, for all roof type, had more coliform count than those collected at the peak of the rain. The presence of coliform bacteria in the rainwater samples collected (for all roof type) is an indication that the harvested water are in a poor 
sanitary state. Table 8 shows the mean of the Most Probable Number of E-coli count on rainwater samples collected from rooftops made of three different roofing materials. The $E$-coli count in all samples ranged from non-detectable

(0) $-0.7 \mathrm{MPN} / 100 \mathrm{ml}$ for onset and peak of rain.

Table 9: Analysis of variance of harvested rainwater quality from

\begin{tabular}{lcrcccc}
\multicolumn{7}{c}{ different rooftop catchment types } \\
\hline \multicolumn{1}{c}{$\begin{array}{c}\text { Source of } \\
\text { Variation }\end{array}$} & $\boldsymbol{S S}$ & $\boldsymbol{d} \boldsymbol{f}$ & $\boldsymbol{M S}$ & $\boldsymbol{F}$ & $\boldsymbol{P}$-value & $\boldsymbol{F}$ crit \\
\hline Between Groups & 874.0492 & 2 & 437.0246 & 0.131607 & 0.877144 & 3.284918 \\
Within Groups & 109582.8 & 33 & 3320.691 & & & \\
Total & 110456.9 & 35 & & & & \\
\hline
\end{tabular}

E-coli count was highest in water sample collected from corrugated Asbestos rooftop for onset and peak of rain, followed by samples collected from galvanized Iron rooftop while samples collected from Aluminum rooftop had the least count. Generally, water samples collected at the onset of the rain had more $E$-coli count than those collected at the peak of the rain for all roof type. However, the presence of $E$ coli (at any level) in water is an indication of fecal contamination from animals or humans waste and this has serious health implication. Mean values showed detectable E-coli count per $100 \mathrm{ml}$ on water samples collected for all roof type as against WHO standard which states that it must not be detectable in any $100 \mathrm{ml}$ sample of water $(0 \mathrm{MPN} / 100 \mathrm{ml}) . E$-coli can cause serious hemorrhagic diarrhea and can have long term, if not fatal, complications. The Analysis of variance result as shown in Table 9 shows that quality of harvested rainwater does not significantly differ among rooftop catchment.

Conclusion and Recommendations: The study analysed and compared water quality of harvested rainfall from three different rooftops in Edo State Central, Edo State. Physical, chemical and bacteriological parameters of the rainwater samples collected from galvanized Iron, Aluminum and Asbestos rooftop catchments for onset of rain (February) and peak of rain (July) showed no much detectable variation pattern of water quality amongst the three selected roof types and thus no roof type can be said to produce superior water quality than the others. Analysis of physical parameters showed that harvested rainwater had slightly higher acidic level when compared to WHO permissible limit for drinking water. Bacteriological qualities of harvested rainwater showed evidence of contamination. The study further shows that for the two (2) rainfall periods (Onset and Peak of rain), none of the roofing materials emerged as clearly superior to the other in terms of the quality of the rainwater harvested. However, samples harvested from Asbestos rooftop had more parameters in which it had the highest contamination level (parameters such as total coliform count and E. coli). These all have serious health implications. For households that intend to harvest rainwater from their rooftop, the use of Aluminum roofing sheets in their building designs should be encouraged. However, if not feasible due to cost constraint, the coated galvanized Iron (Zinc) roofing sheet should be adopted. The use of corrugated asbestos is not recommended. Finally, harvested water should be filtered locally and boiled beyond $100^{\circ} \mathrm{C}$ before potable use. Additional treatment like chlorination may be of great importance.

\section{REFERENCES}

Amin, M. T. and Han, M. Y.( 2009). Roof-harvested rainwater for potable purposes: Application of solar collector disinfection (SOCODIS), Water Res., 43, 5225-5235

Aziegbe F. I. (2006). Sediment sources, redistribution, and management in Ekpoma, Nigeria. J. Hum. Ecol. Vol. 20(4): 259-268.

Badal,S; Giri P. P. and Singh M (2016). Physiochemical, Biological Study of Harvested Rainwater Quality of Greater Noida, G. B. Nagar, U.P., A region of India IJLTEMAS Volume V, Issue IV pp 111-113

Evans, C.A., P.J. Coombes and R.H. Dunstan, (2006). Wind, rain and bacteria: The effect of weather on the microbial composition of roofharvested rainwater. Water Research, 40(1): 3744.

Gbadegesin N and Olorunfemi F (2007). Assessment of rural water supply management in selected rural areas of Oyo State, Nigeria, ATPS, working paper series, No 49

Ghisi, E. and D.F. Ferreira, (2007). Potential for potable water savings by using rainwater and greywater in a multi-storey residential building 
in southern Brazil. Building and Environment., 2512: 22-42.

Grandet, C., P.J. Binning, P.S. Mikkelsen and F. Blanchet, (2010). Effects of rainwater harvesting on centralized urban water supply systems. Water Science and Technology: Water Supply, 10(4): 570-576.

Gromaire-Mertz M.C,.Garnaud, S.Gonzalez, A.Chebbo G (1999). Characterisation of urban runoff pollution in Paris, Water Science and Technology: 39 1-8.

Han, M.Y., (2007): Rainwater's recovery role in Banda Aceh. Water, 21: 47-49.

Hatibu, N., K. Mutabazi, E.M. Senkondo and A.S. K. Msangi, (2006). Economics of rainwater harvesting for crop enterprises in semi-arid areas of East Africa. Agricultural Water Management, 74: 80-86.

Heyworth, J.S., G. Glonek, E.J. Maynard, P.A. Baghurst and J. Finlay-Jones, (2006). Consumption of untreated tank rainwater and gastroenteritis among young children in South Australia. International Journal of Epidemiology. 35: 1051-1058.

Ifabiyi, I. P. (2012). Hydrograph analysis and hydrological zones: tools for watershed and water resources planning in a sub humid tropical catchment, Nigeria. Journal of Geography and Geology, Vol. 4(1): 185-195.

Jackson, R.B., S.R. Carpenter, C.N. Dahm, D.M. Mcknight, R.J. Naiman, S.L. Postel and S.W. Running, (2001). Water in a changing world. Ecological Applications, 11(4): 1027-1045.

Krebs, M.(2010). Nigeria Reports Water Scarcity Across Numerous States. Digital Journal. Nigeria Vision 20: 2020 Volume II: Sectoral Plans and Programmes. Economic Transformation Blueprint.

Lye, D.J.,(2002). Health risks associated with consumption of untreated water from household roof catchment systems. Journal of American Water Resources Association, 38:1301-1306.

Manzungu, E (2004). Farmers' Elected Bodies and Smallholder Irrigation in Zimbabwe. Harare, Weaver Press.
Mathew, B (2005). Ensuring Sustained Beneficial Outcomes for Water and Sanitation Programmes in the Developing World. IRC Occasional Paper Series $40 ;$ p. 12 .

Meera, V. and M.M. Ahammed, (2006). Water quality of rooftop rainwater harvesting systems: a review. Journal of Water Supply Research and Technol. - AQUA 55: 257-268.

Oyedotun T.D.T. (2012). Urban water usage in Egbeda area of Oyo State, Nigeria. World Wide Workshop for Young Environmental Scientists, 12th edition

Retamal, M. and A. Turner, (2010). Unpacking the energy implications of distributed water infrastructure: how are rainwater systems performing?. Water Science and Technology: Water Supply, 10(4): 546-553.

Vasudevan, P. and Pathak, N. (2005). DRWH water quality: A literature review. Centre for rural development and technology, Indian Institute of Technology, Delhi, India. Sub programme C: Health implications. Available: http//www.en.warwick. ac.uk/dtu/rwh/eudocs/c1.Pdf.

WHO (2004): Guidelines for drinking-water quality. Recommendations. Vol.1, $3^{\text {rd }}$ Edition, World Health Organization, Geneva

WHO (2011): Guidelines for drinking-water quality, $4^{\text {th }}$ Edition, World Health Organization, Geneva.

Yufen R.,.Xiaoke, W.Zhiyun, O.Hua Z,.Xiaonan D,.Hong M (2008). Stormwater runoff quality from different surfaces in an urban catchment in Beijing, China, Water Environment Research, 80(8) 719-724.

Zhu, K.,I. Zhang, W. Hart, M. Liu and H. Chen, (2004). Quality issues in harvested rainwater in arid and semi-arid Loess Plateau of northern China. Journal of Arid Environments, 57(4): 487-505.

Zunckel, M., Saizar, C., Zarauz, J., (2003). Rainwater composition in northeast Uruguay, Atmospheric Environment, 37 (12):1601-1611 